\title{
The Effectiveness of Teaching Translation Using the Power of Two Method
}

\author{
Anam Sutopo, Harun Joko Prayitno \\ Universitas Muhammadiyah Surakarta \\ Surakarta, Indonesia \\ anam.stupo@ums.ac.id
}

\begin{abstract}
This study aims at describing the effectiveness of translation teaching using the method of the power of two for the sixth semester students in Department of English Education Universitas Muhammadiyah Surakarta. This research applied the qualitative research in the form of a case study. The study was done in class A, semester VI, Department of English Education of Universitas Muhammadiyah Surakarta in 20172018 academic year consisting of 32 students. The sources of the data were events, informants and documents. To get the data, the researcher used in depth-interview, observation and documentation. The writer applied method and source triangulation. The data were analyzed by using the interactive model. The result of the study shows that teaching translation using the power of two method for the sixth semester students in Department of English Education Universitas Muhammadiyah Surakarta in 2017-2018 academic year is effective enough.
\end{abstract}

Keywords-effectiveness; the power of two; and teaching translation.

\section{INTRODUCTION}

The Translation Course is a compulsory subject for students of the English Department, Teacher Training Education Faculty in Universitas Muhammadiyah Surakarta (UMS). It is as one of the skills that must be mastered by them. The course objective is that the students must able to translate the text from English to Indonesian accurately. This course is given for the fifth semester students.

Teaching translation for the big class is not an essay task5. It happens in the English Department of Universitas Muhammadiyah Surakarta. The class of Translation course consists of many students. This is a big class with 41 students. It needs special management to handle this situation. The result of teaching translation is not good. Most of students have no good performance of translation skill. It becomes a seriuos problem. The lecturer gets problem because of this big class condition. Usually, the problem may occur in all steps of translation process. They are to analyze the text to be translated, to transfer the meaning from source language into target language, and to reconstruct or restructure the translation result and to give some feed backs to students[1]. The low ability of the students in translating this text (from the first language into the second language) becomes the specific phenomenon for teaching this subject in Class C.
The efforts done by the lecturer to solve those problems are by giving explanation in-detail related to the theory of translation and improving the structure mastery[2]. Any how, the efforts are not effective enough to solve the problem. It is due to the fact that the translation skill is not only theoretical understanding but also practical based on various exercises. The students need many exercises to develop their skill. Therefore, the lecturer feels to solve those problems by proposing a new teaching method, namely the interactive method.

The aim of this study is to know the effectiveness of implementing the power of two method in the quality translation learning and developing the students ability in translating English text into Indonesian.

Discussing translation means talking communication2. It needs a process. The process of translation becomes very important since it may reflect the product produced by the translator. It has three components in the process of translation. They are discovering meaning from the source language, determining the main massage, and expressing again the meaning in the target language. Discovering meaning means the translator must read the text to be translated. By reading the text to be translated the translation may get meaning or information given by text[3]. From the information or message obtained from the text to be translated, the translator may transfer it to the target language. In the process of transferring, the translator should determine the suitable meaning between source language and target one. Determining the message is important step. Finally, the translator reconstructs the result of the draft. Finish reconstructing, the translator may give the translation result to the client[4]. It means finish working. It is supported by the statement that there are three major steps when the process of translation happens1. The diagram of translation process can be describe as follows:

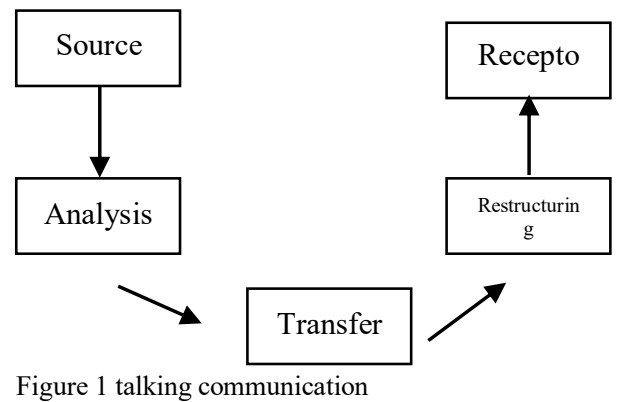


This diagram explains that the translation process of analyzing translated material means to analyze the relationship between grammatical used and constituent parts, identifying the words, phrases, and the semantic units meaning and getting meanings of the grammatical structure and semantic units connotatively. It is an example of English translation as the first language into Indonesian as the second language[5].

\section{SL: The atmosphere and peace in Papua have reached.}

TL : A security situation and peaceful condition in Papua have been realized.

The example above shows that the main meaning is not different when the translator translates the sentence from the first language into the second language. From the example above, it can be understood that the meanings obtained from the first language sentence were transferred well into the second language. It is done completely.

On the other hand, the equal meaning between first text and second text is very important things if the activity of transferring the message from first text into another texts, to find the relationship between the first text and the second text. The translation accuracy has the following definition "translation equivalence occurs when a SL and a TL text are relatable the same features of substance[6]." This statement may have understanding that if the first has many language relations for the features of substance with the second text, it is very possible for the translation accuracy to appears. The translation could not be made only for few meanings but also it should be connected with the factual situations and contexts dealing with the accuracy that must be established5.

When the requirements of the translation accuracy found in the first text and the second text are relatable, the challenges that often got in getting this connection can be caused by the difference traditions and habits of the people who speak or read the second text with their own way of written communication. The examples can be seen in the following:

a. SL: Rumah kaca itu sangat megah sekali.

\section{TL: That laboratory is very sophisticated}

\section{b. SL: lemper}

\section{TL: rice cake}

From the examples above, it can be understood that from point a) the word rumah kaca in first sentence is similar meaning with laboratorium in the second text, therefore there will be no obtained the problem for this working on translation. Anyhow, from the point b) it can be found that the word lemper is not easy to translate into English language. It means that the translator did modification that cake by giving annotation or adding meaning of lemper to meet the match between the meaning found in the first language and second language.

Another meaning of equivalence is accuracy6. The translation accuracy is an urgent part of translation activity. Accuracy becomes the main parameter in giving justification or to determine whether the result of translation has an excellent quality or not. Accuracy also get perception that the meaning found in the first text has been transferred in the target text completely[7]. Basically, accuracy has a close-relationship in choosing the suitable diction in order to reveal the similar expression in the second language. Determining the correct diction is slo very urgent. It is due to the fact that if the translator finding incorrect dictions for the second text, therefore the text will be broken, not valid as well as not be accurate. Deciding the correct dictions must consider three components, they the targeted readers, factual and contextual of the targeted text and the socio - cultural condition.

Accuracy is an evaluation of the accuracy of the translation at the sentential level which is intended to find out whether the content of the source language sentences are accurately rendered into the target language sentences[8]. It can be understood that (a) the message found in the first text is accurately conveyed to the second text. The translated text is clear to tester and no back-translation which is required, (b) the message found in the first text is really accurate conveyed to the second text. The translated material or the translated text could be smoothly understood by the tester, but several backtranslation and some changes in the word order are required, (c) the message found in the first text is really accurate conveyed to the second text. There are several challenges in line choice lexical items and with the relationship between the phrase clause and the sentence elements, and (d) the first text is not translated at all into the second text i.e. it means there is omission or deletion. It means that accuracy is a kind of first text - accurate approach to a translation work. A translation is needed to be accurate if it is correctly and completely conveying the message from the first text to the second text.

To design the program of effective translation learning process may involve needs' analysis, translation outlines, method of learning, the lecturer's role and learners' participation, and evaluation items. Needs analysis means the discrepancy between the actual phenomenon and desired conditions8. Needs analysis may give beneficial in identifying the qualification of the expected learners' groups to learn the second text. Learners' groups must be placed at the appropriate level of competence during the process of learning. The procedure needs the following: (a) having interview with learners of translation gaining the perceptions about the main difficulties in the language being discussed, (b) having interview with different lecturers, and (c) doing observation in line with the level of learners' skills in understanding the material and their learning difficulties9. It is also needed in line with the curriculum or designing of the syllabus which can be used to identify: the needs of learners' learning, availability requirements, outcomes of learners' learning and weaknesses, information in line with the progress needs, and determine the existing deficiencies to achieve the objectives of learning.

Syllabus means the topics outline covering in a single course or graded. On the other hand, it can also be defined that a work specification to be covered over a period of time with a starting point and a final goal, the task specific plan for one period of time that begins and ends appropriately to the purpose10. Syllabus also known as the specified into contentbased, situational, structural and functional, as well as topicbased. Content-based syllabus may combine the factors within 
the materials of learning referring to the users. Syllabus content should be designed by teachers of lecturers and actually does not need the help of others but in fact, syllabus is often made by experts or syllabus developers since their lack ability to design it. There is an explicit meaning related with the language courses will be taught and should include a series of the expected outcomes.

Method of teaching is needed. It has a great role. The teaching method may help the teacher in conveying materials to the students. A good method teaching will be useful. It is due to the fact that teaching's method is presentation of the overall plan of materials performed in a sequence and in a harmony with the established approach of learning11. Method of teaching, curriculum or syllabus design, and goals formulation may have interdependence as human understanding of the psycholinguistic, interactional, and linguistic content of the process that is essentially cognitive.

The power of two is one of the teaching methods implementing in teaching translation. It has procedure to works in translation by doing in a couple of student, working in pairs, then, the correcting one to another. Therefore, method of teaching is extremely important part in the process of teaching learning. On other words, method of teaching may help the lecturer in teaching material effectively or not.

\section{METHOD}

This research applied the qualitative research in the form of a case study. The class A, semester Vi, Department of English Education of Universitas Muhammadiyah Surakarta in 20172018 academic year had been selected to become the location of research. This class consisted of 32 students. The data sources in this research were events, informants and documents. To get the data, the researcher used in depthinterview, observation and documentation[9].

The researcher applied method and source triangulation to validate the data. Finally, the writer used interactive model proposed by Miles and Huberman to analyze the research data.

\section{RESUlT AND DiscUSSION}

The process of teaching translation using the power of two for the sixth semester of English Department of Universitas Muhammadiyah Surakarta is divided into three parts, namely opening, main-activity, and closing. At least, there are four kinds of teaching methods that could be implemented in teaching translation12. The four method of teaching above are interactive, visiting, jig-saw, and the power of two. The following are the steps for teaching translation using the power of two which has been implemented for the sixth semester of English Department of Universistas Muhammadiyah Surakarta in 2017-2018 academic year. They are games, discussions, and drillings. The goal of implementing this step is to give more detailed about prior information in understanding the procedures. It is as method to make students easy to understand with the material of teaching. This method is to empower students' understanding and to improve their translation skill appropriately. For this case, informant E said that he used the power of two for teaching translation by applying opening, analyzing the text, transferring message, working in pair pairm correcting in partnership, and presenting the result in front of the class, and conclusion as well as homework. It's in line with Sutopo's theory about method of teaching translation6.

One of the methods used in improving translation skill is also implementing discussion in the power of two. It is in line with a repeating sentence in the classroom management, or in some parts, carefully doing translation by two persons or more, and also working in pairs dealing with translation work and people in the classroom to prepare for an imaginative argument5[2]. Discussion may help students expanding the classroom management and providing natural contexts for the language being used. Elaborating the method of the power of two is by correcting and giving a way to involve the class, encouraging the students to write up without worrying of set patterns, getting them to use their imaginations, and improving the atmosphere to make them forget that they are in the classroom9. Discussion may also be composed by two until four students. When the group work has been done regularly and justified carefully in the form of giving explanation of it is propose, the class is sooner accepted as a natural activity. In more comprehensive material, the lecturers expect that every student can translate the material and improve by having two group in understanding the material that they discussed. Perhaps, students who didn't understand can ask to their friends so it is enable to students to share their problem each other and students can teach the other students. The method that was implemented by the lecturers in the sixth semester of English Department, Teacher Training and Education Faculty, Universitas Muhammadiyah Surakarta in 2017-2018 academic year was affective. The activity of working in pairs, discussion in two groups and correcting each other with the power of two has really supported by the students of translation and their classroom. The activity aims to encourage student's interaction. It also helps lecturer to expand the classroom management and to provide the natural context for the language being used significantly. The students feel more confident enough for their translation skill by having progress, even they need much more practice. Their skill becomes better than before although there are a lot of students that are still reading the paper when they are translating in the class.

The goal of the lecturing by using this method of the power of two is improving students' enthusiasm and their interest in the translation field. The lecturer must encourages students to active in the classroom activities, such as: doing exercise of translation, giving a chance to translate the materials in outside of the class, doing discussions, sharing students' opinion, practicing in the formal class and also motivating them to be brave students in the class in presenting the result of the group work. There will be a specific goal of teaching translation skill6. The lecturer is always repeating the learning materials when the students didn't comprehend and help them when there is any student needed it. The researcher also found that the students in the class of translation did not concentrate to translate the materials because of the context of classroom condition. Therefore the lecturer tried to make a confirmation that the students felt comfortable in the classroom to continue doing translation exercises and to the teaching learning process. 
The classroom condition at the sixth semester of English Department, Teacher Training and Education Faculty, Universitas Muhammadiyah Surakarta in 2017-2018 academic year was a little noisy but it would be interesting and exciting, not boring. When the lecturer presented the materials of translation to the students, most of them gave much attention although some of them also did not pay attention. The real condition in the classroom may show that there are many students who have paid attention seriously, some others prepared their translation materials, and some others again were doing a little conversation with their closed-friends. Students often made mistakes when they were answering the questions. Mostly the students were passive because they did not know how to translate well in the classroom and always dominated by the clever students. The researcher tried comparing the other lecturer. Informant $\mathrm{M}$ said that the problems faced by the students in the factual condition that they cannot translate well, the students worried in making mistakes when they were translating, they could not think of anything to say. The students claimed that they had no motivation and felt difficult to express the work in translating in the classroom. When they were taking part in translation, they were still shy in getting attention and they were fearful of criticism or losing face when they did translation exercises.

The lecturer had many roles in making the students safe, nice, comfortable, and enjoy the teaching learning process of translation using the power of two method. The lecturer convinced that the students could do the task and examination successfully. They were also having the role to seek some ways to improve students' ability through discussion and work in pair. Lecturer guided the students when they got serious problems and difficulties in their work. The roles of the lecturer are as controller, assessor, corrector, organizer, prompter, resource. Based on the result of researcher observation in the classroom and interviewing some students, there are three roles of lecturer in teaching translation for sixth semester of English Department of Universistas Muhammadiyah Surakarta in 2017-2018 academic year by using the power of two method. They are lecturer as motivator, facilitator and organizer. They always altered from one activity to another. Finally, after triangulating with the data the writer may conclude that the roles of lecturer at campus are controller, observer, corrector, prompter, resource and assessor. The lecturer has awareness to the role of teaching translation using the power of two method in aiding student to attain their ideal objectively by enduring them continuously to study hard. It means that the main goal in the teaching of translation to learner is able to transfer the meaning or message well.

Meanwhile, to support the effectiveness of teaching translation using the power of two method at the sixth semester of English Department of Universitas Muhammadiyah Surakarta in 2017-2018 academic year, the students' roles in translation activity were 1) the students are as the monitor and evaluator for their own progress. Students as monitor and evaluator mean that the students could see how far they get understanding the material. If the students feel that their result was bed, they could evaluate their self. They could change the learning style, activities in the classroom, the students learned their translation skills and tried to be active in discussions with their groups[10]. They are also able to see their score when they are active in the classroom. 2) the students are the members of a group that learn the interacting among the ways students. The students did the learning process and doing interaction one to another to discuss the result. The students tried to practice what the lecturer had instructed and did all of the step given by him. For example: the students must do a good performing in translation skill. It's appropriate with Johnson and Paulston theory that stated students' role in teaching translation using the power of two approach to language learning are: a) the student is as the planner of his or her own learning program and thus ultimately assumes their responsibility for what he or she did in the classroom; b) The student is as a monitor and evaluator for his or her own progress of work; c) The student is also a member of the group and they are learning by interacting one to another; d) The student is a tutor of other learners; e) The student learns from the lecturer, from other students, and from other teaching formal sources. It revenues that student's role is the essential thing that lecturer had to pay attention in engaging the teaching learning process. As the result of observation and analysing the data, it is brief that students have revealed the performances through the activities conducted by the lecturer. Understanding the material, doing assignment, listening to lecturers' explanation, and doing the presentation. Being attentive, attractive, enthusiasm and active participant and good translator.

The problems faced by lecturer to improve the effectiveness and the implementation of teaching translation using the power of two method is to overcome the problems existing in class like; 1) when the class is in noisy situation, the lecturer must check the students by taking an additional practice and asking them to pay attention more and more. 2) when the lecturer is teaching the material and the time is over, the lecturer must end it and directly gave a little information and conclusion covering all of the materials on that day. 3) for the students having low ability in translation, the lecturer must give a special attention and treatment to the student deeply in order to build a competence. It means that empowering character and competence could be started from heart to heart. Finally, the lecturer must provide feedback to the students in the classroom to get their attention in line with the translation materials. The researcher also tried to compare to other researches. In the finding, it was stated that university EFL students regardless of their English proficiency levels used fluency-oriented strategies the least frequently9. Hence, lecturer has a great and successful solution, like; helping the students increasing their communicative skills and competence by using oral communication strategies in proper contexts. Particularly, lecturers must highly be encouraged to provide the students with correct and accurate information of different types of oral communication strategies since the students may not be aware of the potential effectiveness of these strategies on their translation skill.

Based on the interviews conducted by lecturer for the sixth semester of English Department, Teacher Training and Education Faculty, Universitas Muhammadiyah Surakarta in 2017-2018 academic year, it could be concluded that the lecturer have several solutions to their students. The result of 
the interview with informant D said that the lecturer did not only taught the students but also gave highly motivation to the students in the classroom of translation. She also gave many tasks to practice their translating at home or school that is motivated their students in the teaching learning activities on translation.

In general, the teaching translation using the power of two method for the sixth semester of English Department, Teacher Training and Education Faculty, Universitas Muhammadiyah Surakarta in 2017-2018 academic year can be considered as professional lecturer. There are several aspects which still need to improve. The first aspect is, in line with the lecturer's lesson plan, Lesson plan is important in the effort of creating an effective teaching and learning activity. Therefore, the students must improve the quality of their lesson plan in order to improve the quality of teaching and learning process.

The next aspect which needs to improve is the variety of teaching activities provided for the students. Providing various ways for the students who have helped the lecturer avoiding students' boredom. As found in the research findings, most of the lecturers have been familiar with monotonous activity for the students[4]. The students will be less motivated if the lecturer did this in a long period of time. Since the process of teaching and learning will be more effective if the students are highly motivated. The lecturer needs to think of any possible variation in their teaching in order to improve the students' skill in line with translation.

\section{CONCLUSION}

The method used by the lecturer for teaching translation for the sixth semester students of English Department of Universistas Muhammadiyah Surakarta in 2017-2018 academic year using the power of two are opening, main-activity and closing. The activity aims at encouraging them and student's interaction. The power of two method also helps lecturer in expanding the classroom management and providing natural context for the language being used. The students feel confident enough that translation saving some progress even, it needs much more practices. The grammar used was getting better in improving the skill and making the teaching of translation more effective although there are a lot of students still read the materials only when they are translating in the classroom. The condition at the sixth semester of English Department of Universistas Muhammadiyah Surakarta in 2017-2018 academic year was a little noisy, however, it becomes more interesting and exciting, not boring.

When the lecturer presented the translation materials to the students, most of them gave much attention but some of them also didn't pay attention. There are many students who paid attention seriously, while others prepared their translation materials or do a little conversation with their closed-friends. Teaching translation using the method of the power of two becomes more effective. Students often make mistakes when they are translating the text and giving answer to the questions. Few students could be passive because they did not know how to translate well in the classroom and the activities in the classroom were still dominated with clever students. The solutions used by lecturer of the sixth semester of English Department of Universitas Muhammadiyah Surakarta in 20172018 academic year is the lecturer does not only teach the students but also gives positive and significant motivations to the students in the classroom. She also gives the assignments to practice translation at home and always motivates their students in the teaching learning activities.

The lecturer roles in teaching translation for the sixth semester students of English Department, Universitas Muhammadiyah Surakarta in 2017-2018 academic year are as controller, observer, corrector, resource and assessor. The lecturer has had awareness of his role to aid students to attain their ideal objective by enduring them to study hard and doing many exercises of translation. The proper method could be an alternative strategy in improving the students translation skill. It also gives some positive and significant effects on the students' skill, motivation, attitude, participation, friendship, and also scores.

\section{REFERENCES}

[1] P. Reason and H. Bradbury, Handbook of action research: Participative inquiry and practice. Sage, 2001.

[2] A. Sutopo, "Terjemahan \& penerjemahan dalam lintas pemahaman," Sukoharjo CV. Jasmine, 2015.

[3] B. H. Hoed, "Ideologi dalam penerjemahan," Solo Konas Penerjemahan, 2003.

[4] R. Machali, Pedoman bagi penerjemah. PT. Grasindo, 2000.

[5] D. Nunan, Practical English language teaching. McGrawHill/Contemporary, 2003.

[6] J. C. Catford, A linguistic theory of translation. Oxford University Press, 1978.

[7] A. Sutopo, "Penerjemahan Naskah Resmi: Telaah Holistik Naskah Pidato Kenegaraan." Surakarta: Muhammadiyah University Press (MUP), 2015.

[8] M. R. Nababan, Teori menerjemah bahasa Inggris. Pustaka Pelajar, 1999.

[9] Sutopo. H.P, Penelitian Kualitatif. UNS Press, 2005.

[10] H. D. Brown and H. Lee, Teaching by principles: An interactive approach to language pedagogy, vol. 1. Prentice Hall Regents Englewood Cliffs, NJ, 1994. 